\title{
Phthalate ester plasticizers in freshwater systems of Venda, South Africa and potential health effects
}

\author{
OS Fatoki ${ }^{1 *}$, M Bornman ${ }^{2}$, L Ravandhalala ${ }^{3}$, L Chimuka ${ }^{4}$, B Genthe $^{5}$ and A Adeniyi ${ }^{6}$ \\ ${ }^{1}$ Department of Chemistry, Faculty of Applied Sciences, Cape Peninsula University of Technology, \\ PO Box 652, Cape Town 8000, South Africa \\ ${ }^{2}$ Department of Andrology, University of Pretoria, South Africa \\ ${ }^{3}$ Department of Environmental Resources Management, University of Venda, South Africa \\ ${ }^{4}$ Department of Chemistry, University of the Witwatersrand, South Africa \\ ${ }^{5} \mathrm{CSIR}$, Stellenbosch, South Africa \\ ${ }^{6}$ Department of Chemistry, Lagos State University, Nigeria
}

\begin{abstract}
Phthalate ester plasticizers were determined in rivers and dams of the Venda region, South Africa. Liquid-liquid extraction, column chromatographic clean-up and capillary gas chromatography were the methods used for the quantitative analyses. Levels of phthalates in water samples from the rivers and dams ranged from $0.16 \mathrm{mg} / \ell$ to $10.17 \mathrm{mg} / \ell$ and varied between $0.02 \mathrm{mg} / \mathrm{kg}$ and $0.89 \mathrm{mg} / \mathrm{kg}$ in sediments. Generally, the highest concentrations of phthalates were found as DBP and DEHP, which is consistent with their common use in plastic materials and other industrial chemicals. The phthalate levels found in the water samples were much higher than the criterion of $3 \mu \mathrm{g} / \ell$ phthalates recommended by the United States Environmental Protection Agency (USEPA) for the protection of fish and other aquatic life, and higher than the Suggested No-Adverse Effect Levels (SNAEL) of 7.5 to $38.5 \mu \mathrm{g} / \ell$ for drinking water. The health risk-assessment studies on the phthalates found in the water systems suggested potential carcinogenic and other toxic effects they may pose to communities downstream which might be exposed either through drinking untreated water from the rivers, through dermal absorption or by using the freshwater sources to water their vegetable gardens. DEHP posed the highest risk potential of all the phthalates and the water use or exposure pathway that appeared to pose the highest potential health risk for carcinogenic as well as toxic effects was vegetable watering. The results for phthalates in the water samples give cause for environmental concern as people's health downstream is at stake if rural populations use this water.
\end{abstract}

Keywords: capillary GC, phthalates, freshwaters, potential carcinogens

\section{Introduction}

Phthalates are among the most widely used industrial chemicals in existence. They are used principally as plasticizers, to impart flexibility, workability, and durability to polymers, but they can also be found in products such as adhesives, inks, and cosmetics, munitions, industrial and lubricating oil, as well as solvents in perfumes and paints and additives in hair-sprays and insect repellent (Shanker et al., 1985; Ling et al., 2007; Huang et al., 2008). To provide flexibility phthalate esters are not chemically bonded to resin and therefore are easily released (Yuan et al., 2008). The most commonly used phthalate plasticizers are di-2-ethylhexyl phthalate (DEHP) and di-n-butyl phthalate (DBP) with the others used only for selective applications (ATSDR, 2006).

There has been growing interest in the unusual ubiquity of phthalates in the environment (Fatoki and Vernon, 1990; Fatoki and Ogunfowokan, 1993a) and their wide range of toxicological characteristics (Blount et al., 2000). Phthalates have possible tetratogenic and carcinogenic effects (Blount et al., 2000; Tomita et al., 1982; Huff and Kluwe, 1984). DEHP has been included in Class B2 (probable human carcinogens) (Alatriste-Mondragon,

\footnotetext{
* To whom all correspondence should be addressed.

용 +2721460 3219; fax: +2721 4603905 ;

e-mail: FatokiO@cput.ac.za

Received 25 August 2009; accepted in revised form 2 December 2009.
}

et al., 2003). They are also suspected endocrine disruptors (Fredricsson et al, 1993). A study by Colon et al. (2000), in which Puerto Rican girls with premature breast development had higher levels of blood phthalates compared to other girls, suggested an association between phthalate exposure and abnormal reproductive development. Testicular toxicity of phthalates has been documented. Studies have indicated that these chemicals may affect sperm cells, sperm mobility, chryptorchidism and hypospadias, in laboratory animals (Imajima et al., 1993; Poon et al., 1997; Arcadi et al., 1998).

A main route of exposure to phthalates is via water use as these chemicals find their way into the water system through effluent discharges and leaching from waste dumps, and through several diffuse sources (WHO, 2003).

Several attempts have been made to determine levels of phthalates in the aquatic environment by gas liquid chromatography with electron capture detection (Ritsena et al., 1989) and FID (Fatoki and Noma, 2002). Other methods include the use of GC-MS (Jeng, 1986; Yuan, et al. 2002; Li, et al., 2006) and differential pulse polarography (Tanaka and Takeshita, 1984). Extraction techniques include liquid-liquid extraction with clean-up technique (Fatoki and Ogunfowokan, 1993b), solid-phase extraction methods (Fatoki and Noma, 2002; Li et al., 2006) and micro solid-phase extraction (Li et al., 2006). A major problem in the analysis of environmental samples is the reduction of background contamination to levels below that of the very low levels generally present in the samples. 
This problem of background contamination is more serious in trace analysis of phthalates than other pollutants (including the chlorinated hydrocarbons) because phthalates are present in almost all equipment and reagents used in the laboratory (Giam and Wong, 1972).

This study assessed the levels of phthalates in freshwater systems of Venda, South Africa and investigated the potential health effects of the chemicals in the water systems. The Venda region of South Africa is mostly rural and indiscriminate disposal of plastic materials is common. In addition, waste management practices are simple thus leaving room for possible gross pollution of the rivers by these chemicals. Many of the rivers and dams serve as primary domestic freshwater resources for the rural communities downstream, which exposes them to these chemicals, with potential health consequences.

\section{Materials and methods}

\section{Instrument}

Analysis was undertaken using the Perkin Elmer Clarus 500 Gas Chromatograph, with FID detector and capillary column (Col-Elite 5 to $30 \mathrm{~m}, 0.25 \mu \mathrm{m}$ to $0.25 \mathrm{~mm}$ ) supplied by Perkin Elmer SA (Pty.), Ltd., Cresta, Johannesburg, South Africa. The gas chromatograph had an auto-injection, dual column system for both FID and ECD. The chromatograms were handled by a total Chrom Work Station supplied by Perkin Elmer, South Africa.

\section{Optimising GC conditions}

GC conditions like oven inlet temperatures, carrier gas flow, and detector temperature were optimised as follows: oven (initial temperature of $180^{\circ} \mathrm{C}$, ramp rate of $12^{\circ} \mathrm{C} / \mathrm{min}$, final temperature of $280^{\circ} \mathrm{C}$ with 2 and 7 min hold time, respectively), injector temperature of $180^{\circ} \mathrm{C}$, carrier gas set point of $2.00 \mathrm{ml} / \mathrm{min}$.

\section{Retention times and response factors}

The phthalate esters determined were dimethyl phthalate (DMP), diethyl phthalate (DEP), dibutyl phthalate (DBP) and di-(2-ethylhexyl) phthalate (DEHP). The internal standard used was n-butyl benzoate. The esters and the internal standard were obtained from SUPELCO and Fluka AG, South Africa. The stock solution $(1000 \mathrm{mg} / \ell)$ for each ester was prepared in a $20 \mathrm{~m} \ell$ volumetric flask with methanol (analytical grade), diluted as appropriate and stored at $4^{\circ} \mathrm{C}$. All stock preparations were prepared using glass containers. Using the optimised GC conditions the retention times $(\mathrm{min})$ were obtained. Using a mixture of the phthalate esters and internal standard (n-butyl benzoate) at $100 \mathrm{mg} / \ell$ concentration with 10 replicate injections $(1 \mu \ell)$, the response factors were calculated as follows: area of the peak of phthalate ester/area of the peak internal standard.

\section{Detection limits of the GC system for the phthalate esters}

The detection limits were determined for the phthalate ester plasticizers using the method described by Miller and Miller (1984).

\section{Quality assurance studies}

Water samples of $500 \mathrm{~m} \ell$ (distilled and de-ionised water) were pre-extracted in triplicate with $3 \times 20 \mathrm{~m} \ell$ dichloromethane
(DCM) in a glass separator funnel. They were then respectively spiked with $1 \mathrm{~m} \ell$ of $10 \mathrm{mg} / \ell$ mixtures of the phthalates. Each spiked water sample was extracted with $3 \times 20 \mathrm{~m} \ell$ DCM after acidification with $5 \mathrm{m \ell} \mathrm{H}_{2} \mathrm{SO}_{4}$ and salting out with $50 \mathrm{~g}$ $\mathrm{NaCl}$. Sediment samples of $10 \mathrm{~g}$, air-dried and sieved $(0.45 \mu \mathrm{m}$, pore size), also in triplicate, were pre-extracted in a Soxhlet extractor with about $120 \mathrm{~m} \ell$ DCM. The pre-extracted sediment samples were spiked with standard phthalate ester and again extracted with $120 \mathrm{~m} \ell$ DCM in a cleaned Soxhlet extractor. The extracts were left to dry at ambient temperature in a glass container and reconstituted with about $2 \mathrm{~m} \ell \mathrm{DCM}$.

\section{Column chromatographic clean-up}

A glass column was packed with about $5 \mathrm{~g}$ silica gel (Kieslgel Merck 60, 230 to 400 mesh) in $20 \mathrm{~m} \ell$ of hexane with a 0.5 to $1.0 \mathrm{~m} \ell$ top layer of anhydrous $\mathrm{Na}_{2} \mathrm{SO}_{4}$. The reconstituted phthalate residues from both water and sediment extracts, were run separately through the column and then eluted successively with hexane and about $20 \mathrm{~m} \ell$ benzene ethyl acetate mixture (95:5) (Fatoki and Ogunfowokan, 1993b). The benzene/ethyl acetate eluants were allowed to dry separately and then redissolved in hexane with internal standard and then run on the GC using the optimum conditions described above. The eluants were left to dry at room temperature respectively in a glass container to form a residue.

\section{GC analysis}

The benzene/ethyl acetate eluant residues were reconstituted with $0.5 \mathrm{~m} \ell \mathrm{n}$-butyl benzoate (internal standard) solution and transferred into the GC glass sample vials for analysis using the GC conditions described above.

\section{Determination of blank levels for water samples}

DCM extracts from un-spiked distilled de-ionised water samples were processed as described above for extracts from spiked water samples to establish blank levels.

\section{Routine analysis of water and sediment samples}

Water samples in about $1 \ell$ glass containers were collected from major rivers and dams in Venda. They were immediately acidified with about $5 \mathrm{~m} \ell$ conc. $\mathrm{H}_{2} \mathrm{SO}_{4}$ to preserve the samples and stored in a refrigerator at $4{ }^{\circ} \mathrm{C}$ until time of analysis. Sediment samples were collected from the same water sources in glass containers and also stored at $4^{\circ} \mathrm{C}$ in a refrigerator until time of analysis.

Water: Each $500 \mathrm{~m} \ell$ of water sample was salted with $50 \mathrm{~g}$ $\mathrm{NaCl}$ in a $1 \ell$ separatory funnel. The sample was then extracted with $3 \times 20 \mathrm{~m} \ell$ DCM. The combined extracts were left to stand until dry at room temperature. The dried extract was reconstituted with $2 \mathrm{~m} \ell \mathrm{DCM}$ and run on the chromatography clean-up column and GC was determined as described previously.

Sediment: $10 \mathrm{~g}$ air-dried and sieved $(0.45 \mu \mathrm{m}$ pore size $)$ samples were Soxhlet-extracted for $10 \mathrm{~h}$ with $120 \mathrm{~m} \ell$ DCM. After extraction the extracts were left to stand in a clean glass container in a fume cupboard at ambient temperature until dry. The extracts were then diluted with $2 \mathrm{~m} \ell$ DCM to prepare them for column chromatography clean-up and GC was determined as described previously. 


\section{Health risk assessment of phthalates in the river water}

The general human health risk assessment process consists of 4 distinguishable but interacting phases, generally referred to as:

- Hazard identification

- Dose-response assessment

- Exposure assessment

- Risk characterisation (NRC, 1983)

Hazard identification involves substantial evidence that the chemical constituent is found in the water. Combined with occurrence information, there should be evidence of potential or actual toxicity of the chemical constituent. Based on this, potentially hazardous chemicals are divided according to their effects and response (mode of action). For risk-estimation purposes, chemicals are divided into 3 main groups: toxic chemicals, carcinogens and endocrine disruptors (WHO, 2003).

Exposure assessment is a key phase in health risk assessment, because without exposure even the most toxic carcinogenic compound is not hazardous. Exposure assessment involves the identification of potential receptors, exposure pathways, exposure media and receptor behaviour, which affects exposure duration (NRC, 2003). For human health risk assessment, the receptors are generally members of the public who may be exposed to hazardous substances. In this case, the study would focus on resident communities in the area making use of the various water sources for domestic purposes as well as watering homegrown vegetables.

The Health Risk Assessment Programme (Risk Assistant ${ }^{\mathrm{TM}}$, 1995) was used to calculate the potential exposure concentrations. The exposures considered in the assessment include:

- Ingestion via drinking of untreated water

- Dermal absorption due to daily washing/bathing activities in river water

- Watering of vegetables with untreated water

In a quantitative health risk assessment, numerical estimates of human exposure to toxic effects are expressed in terms of average daily dose (ADD), which is the amount of substance taken into the body on a daily basis during the exposure period and is calculated as:

$$
A D D=\left(C_{\text {medium }} \times I R \times E D \times F_{d}\right) / B W \times A T(\mathrm{mg} / \mathrm{kg} \cdot \mathrm{d}),
$$

where:

$A D D$ is the average daily dose

$C_{\text {medium }}$ is the concentration in the contaminated water

$I R$ is the daily intake rate

$E D$ is the exposure duration

$F_{c}$, the fraction contaminated

$B W$ is the body weight

$A T$ is the lifetime averaging time

For risk of carcinogens for exposures that last less than lifetime, the dose is adjusted using the formula:

$$
L A D D=A D D \times(E D / L f t)
$$

where:

$$
L f t \text { is lifetime }
$$

\section{Exposure parameters used to calculate exposure estimates}

The dose (or exposure concentration) values presented in this assessment reflect not only the concentrations of contaminant in various environmental media and exposure pathways selected for analysis, but also the specific numerical parameters applied to each exposure scenario. Different pathways can lead to varying degrees of selectivity severity in health effects.

The following table summarises the exposure parameters used in this assessment.

\begin{tabular}{|l|l|}
\hline \multicolumn{2}{|c|}{$\begin{array}{c}\text { Table 1 } \\
\text { Exposure parameters used to generate } \\
\text { exposure dose estimates }\end{array}$} \\
\hline Specific parameters & Unit \\
\hline Body weight & $70 \mathrm{~kg}$ \\
\hline Lifetime & $70 \mathrm{yr}$ \\
\hline Exposure period & $30 \mathrm{yr}$ \\
\hline Drinking water & $\begin{array}{l}350 \text { events } / \mathrm{yr} ; 2 \text { l/event; 100\% } \\
\text { fraction contaminated }\end{array}$ \\
\hline Dermal absorption & $\begin{array}{l}350 \text { events } / \mathrm{yr} ; 12 \mathrm{~min} / \mathrm{event} ; \\
2300 \mathrm{~cm}^{2} \mathrm{skin} \text { surface }\end{array}$ \\
\hline Vegetab le watering & Daily $40 \%$ of $0.2 \mathrm{~kg} /$ event \\
\hline
\end{tabular}

\section{Tran-media concentrations: calculations}

For some exposure scenarios a contaminant concentration specified in one environmental medium must be converted to a concentration in another medium to which a person is exposed. For instance, crops in soil polluted with DEHP or irrigated with DEHP-polluted water may contain increased concentration concentrations (WHO, 1996). The equation in Risk ${ }^{*}$ Assistant ${ }^{\mathrm{TM}}$ (1996) was used in this assessment to predict such cross-media contaminant, specifically to calculate the concentrations in vegetables. The equation in US-EPA (1992) was used to calculate the absorbed dose of chemical per square centimetre of skin per event for the dermal absorption calculations.

\section{Risk characterisation}

Risk was calculated for exposure to phthalates assuming that people were making use of the river water as their sole source for domestic purposes as well as for watering home-grown vegetables.

For chemicals that cause cancer, risk was calculated as a function of oral potency factor or slope $(\beta)$ and dose. This is approximated by the equation (Risk Assistant ${ }^{\mathrm{TM}}$, 1995):

Risk $=\beta \times$ LADD; the risk estimates represent the theoretical excess cancer risk.

This is the risk of developing cancer in addition to the background cancer incidence, e.g., if the cancer risk is described as $1 \cdot \mathrm{e}^{-5}$ which is 0.00001 or $1 / 100000$, then it can be said that there is an excess risk of developing cancer of 1 in 100000 . WHO (2003) defines the acceptable risk level as 'an estimated upperbound excess lifetime cancer risk of one additional cancer per 100000 of the population ingesting water containing the substance at the set guideline value for 70 years (life expectancy)'. Regulatory authorities should, however, make an informed decision based on collected risk estimation information and decide on an acceptable risk level for local circumstances. 


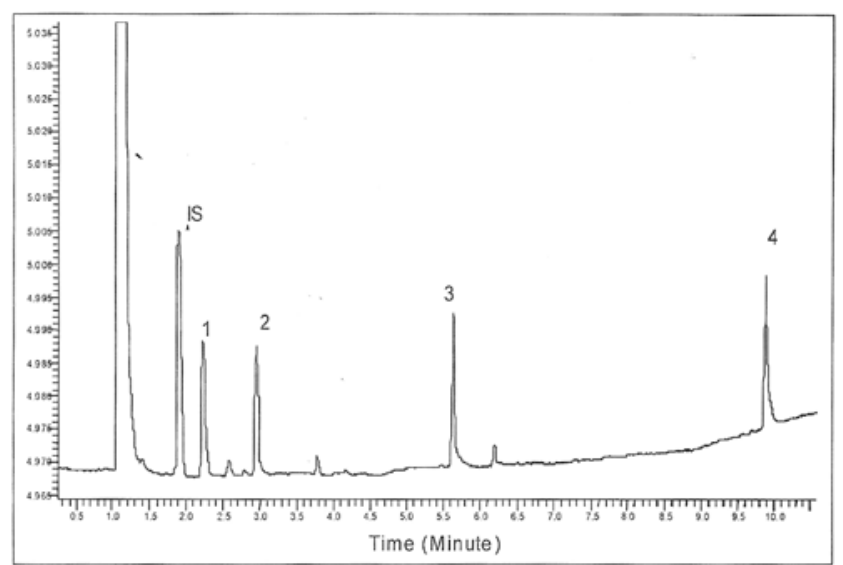

Figure 1

Gas chromatogram of phthalate ester standards (IS - $n$ butyl benzoate; 1 - dimethyl phthalate; 2 - diethyl phthalate; 3 - dibutyl phthalate; 4 - diethyl hexyl phthalate)

Table 2

Levels of phthalate ester plasticizers in water samples $(\mathrm{mg} / \mathrm{l})$ used for risk calculation

\begin{tabular}{|l|l|l|l|}
\hline Sample site & DEHP & DBP & DEP \\
\hline Marais Dam & 0.3 & 4.16 & 3.25 \\
\hline Rietvlei Dam & 0.43 & 4.44 & 3.4 \\
\hline Lotoyanda River & 1.89 & 6.04 & 3.56 \\
\hline Xinkundu River & 0.33 & 7.07 & 0.16 \\
\hline Nzhelele River & 1.3 & 3.83 & 3.27 \\
\hline Mutshindudi River & 0.96 & 5.99 & 3.53 \\
\hline Mutale River & 2.18 & 10.17 & 3.31 \\
\hline Luvuvhu River & 0.69 & 3.42 & 3.33 \\
\hline Dzindi River & 0.84 & 5.44 & 3.19 \\
\hline
\end{tabular}

For toxic chemicals, a hazard quotient (HQ) is calculated, which compares the expected exposure to the agent to an exposure that is assumed not to be associated with toxic effects. For oral or dermal exposures, the average daily dose (ADD) is compared to a reference dose $(\mathrm{R} f \mathrm{D})$. The risk is approximated using the formula:

Risk (hazard quotient) $=\mathrm{ADD} / \mathrm{R} f \mathrm{D}$; A risk estimate of more than 1 is considered to be unacceptable.

The chemical concentrations in Table 2 were used in the risk calculations based on waters analysed.

\section{Results and discussion}

The phthalates were eluted from the gas chromatographic column in the order DMP, DEP, DBP and DEHP. The retention times (minutes) for phthalate esters using the optimised GC conditions were DMP - 2.2, DEP - 3.0, DBP - 5.7 and DEHP 9.0 (Fig. 1). The detection limits of the GC system for the esters were DMP - $20 \mathrm{ng} / \ell$, DEP - $10 \mathrm{ng} / \ell, \mathrm{DBP}-4 \mathrm{ng} / \ell$ and DEHP $-1 \mathrm{ng} / \ell$.

The recoveries obtained from triplicate spiking experiments and elution with 95:5 ratio (v/v) of benzene/ethyl acetate were DMP - 82.14 $\pm 1.32 \%$, DEP - $89.72 \pm 0.52 \%$, DBP $-86.47 \pm 0.39 \%$ and DEHP - $90.70 \pm 0.32 \%$ for water samples. The recoveries for spiked sediment samples were DMP $89.08 \pm 0.51 \%$, DEP $-89.95 \pm 0.34 \%$, DBP $-88.72 \pm 0.55 \%$ and

\begin{tabular}{|c|c|c|}
\hline \multicolumn{3}{|c|}{$\begin{array}{c}\text { Table } 3 \\
\text { Percentage recoveries of phthalate ester from } \\
\text { spiked pre-extracted water and sediment samples }\end{array}$} \\
\hline Phthalate esters & Water & Sediment \\
\hline \multirow[t]{3}{*}{ Dimethyl phthalate (DMP) } & 80.54 & 89.65 \\
\hline & 82.08 & 88.42 \\
\hline & 83.77 & 89.18 \\
\hline Average \% recovery (DMP) & $2.14 \pm 1.32$ & $89.08 \pm 0.51$ \\
\hline \multirow[t]{3}{*}{ Diethyl phthalate (DEP) } & 90.05 & 89.84 \\
\hline & 88.98 & 90.41 \\
\hline & 90.12 & 89.60 \\
\hline Average \% recovery (DEP) & $9.72 \pm 0.52$ & $9.95 \pm 0.34$ \\
\hline \multirow[t]{3}{*}{ Dibutyl phthalate (DBP) } & 86.11 & 88.71 \\
\hline & 86.29 & 88.04 \\
\hline & 87.02 & 89.04 \\
\hline Average \% recovery (DBP) & $86.47 \pm 0.39$ & $88.72 \pm 0.55$ \\
\hline \multirow[t]{3}{*}{ Di-(2-ethylhexyl) phthalate (DEHP) } & 90.74 & 88.44 \\
\hline & 91.08 & 89.07 \\
\hline & 90.29 & 89.61 \\
\hline Average \% recovery (DEHP) & $90.70 \pm 0.32$ & $89.04 \pm 0.4$ \\
\hline
\end{tabular}

DEHP - $89.04 \pm 0.48 \%$ (Table 3). This was judged acceptable for the quantitative determination of phthalate esters in water and sediment samples.

The blank determination with distilled de-ionised water gave a clean background with no contamination by phthalate esters.

Numerous methods have been described for the clean-up of phthalate esters prior to analysis by gas chromatography (Fatoki and Vernon, 1990; Giam et al., 1975; Fatoki and Ogunfowokan, 1993a; Tanaka and Takeshita, 1984). The most commonly used solid phases for separation /clean-up of environmental samples were deactivated florisil, (Giam et al., 1975), alumina and silica gel (Fatoki and Ogunfowokan, 1993a). The eluting solvents used for phthalates were diethyl ether in petroleum (Giam et al., 1975) and benzene in ethyl acetate (Fatoki and Vernon, 1990; Fatoki and Ogunfowokan, 1993a).

All of the selected rivers are perennial and Luvuvhu, Mutale, Dzindi, Mutshindudi, and Nzhelele are the main river channels. Lotanyanda and Xikundu are the tributaries but many of the rivers serve as primary and/or secondary domestic water sources for several communities located downstream.

The levels of phthalates found in the water samples and sediments from the rivers and dams are shown in Tables 4 $\& 5$. The measured levels of phthalates in the rivers varied between $0.16 \mathrm{mg} / \ell, \mathrm{DEP}$ in Xinkudu River and $10.17 \mathrm{mg} / \ell$, DBP in Mutale River). Levels in the dams ranged from 0.30 $\mathrm{mg} / \ell$, DEHP in Marais Dam to $5.70 \mathrm{mg} / \ell$, DBP in Rietvlei Dam (Table 4).

DMP was not detected in all the water samples. The DEP concentrations varied between $0.16 \mathrm{mg} / \ell$ (Mutale River) and $4.04 \mathrm{mg} / \ell$ (Vley) while levels of DBP ranged from $3.08 \mathrm{mg} / \ell$ (Nzhelele River) to $10.17 \mathrm{mg} / \ell$ (Mutale River). The levels of DEHP also varied between $0.33 \mathrm{mg} / \ell$, DEHP in Xinkudu River to $2.78 \mathrm{mg} / \ell$ (Channel).

The concentration of phthalates in sediments varied between $0.02 \mathrm{mg} / \mathrm{kg}$ for DEHP in most of the sediment samples to $6.50 \mathrm{mg} / \mathrm{kg}$, DBP (Channel). DMP was detected in only one of the sediment samples, at $0.16 \mathrm{mg} / \mathrm{kg}$ (Table 5). DEP levels ranged from $0.16 \mathrm{mg} / \mathrm{kg}$ in many of the samples to 0.32 $\mathrm{mg} / \mathrm{kg}$ (Channel) and DBP levels varied between $0.19 \mathrm{mg} / \mathrm{kg}$ in Nzhelele River to $6.50 \mathrm{mg} / \mathrm{kg}$ (Channel). The concentration of DEHP ranged from $0.02 \mathrm{mg} / \mathrm{kg}$ in many samples to 


\begin{tabular}{|c|c|c|c|c|c|c|}
\hline $\begin{array}{c}\text { Varia } \\
\text { san } \\
\text { pht }\end{array}$ & $\begin{array}{l}\text { tion of phthalate } \\
\text { nples }(1=\text { represe } \\
\text { thalates used for } \\
\text { det }\end{array}$ & $\begin{array}{l}\text { able } 4 \\
\text { esters ( } \\
\text { ntative } \\
\text { risk calc } \\
\text { ectable) }\end{array}$ & llatic & on; $\mathrm{N}$ & $D=$ & $\begin{array}{l}\text { later } \\
\text { of } \\
\text { oot }\end{array}$ \\
\hline $\begin{array}{l}\text { Sample } \\
\text { No }\end{array}$ & Sampling 'point & Date & DMP & DEP & DBP & DEHP \\
\hline 1. & Marais Dam ${ }^{1}$ & $15 / 9 / 04$ & $\mathrm{ND}$ & 3.25 & 4.16 & 0.30 \\
\hline 2. & Marais Dam & $17 / 01 / 05$ & $\mathrm{ND}$ & 3.33 & 5.12 & 0.58 \\
\hline 3. & Marais Dam & $22 / 03 / 05$ & ND & 3.16 & 5.48 & 0.79 \\
\hline 4. & Marais Dam & $28 / 07 / 05$ & ND & 3.44 & 4.64 & 0.55 \\
\hline 5. & Channel & $15 / 09 / 04$ & ND & 3.53 & 4.69 & 0.64 \\
\hline 6. & Channel & $23 / 11 / 04$ & ND & 3.19 & 4.78 & 0.86 \\
\hline 7. & Channel & $17 / 01 / 05$ & ND & 3.21 & 3.84 & 0.42 \\
\hline 8. & Channel & $22 / 03 / 05$ & $\mathrm{ND}$ & 3.63 & 4.97 & 2.78 \\
\hline 9. & Channel & $28 / 07 / 05$ & ND & 3.23 & 5.30 & 0.58 \\
\hline 10. & Rietvlei Dam & $15 / 09 / 04$ & ND & 3.91 & 4.89 & 0.51 \\
\hline 11. & Rietvlei Dam & $23 / 11 / 04$ & $\mathrm{ND}$ & 3.23 & 5.70 & 0.33 \\
\hline 12. & Rietvlei Dam & $18 / 01 / 05$ & $\mathrm{ND}$ & 3.18 & 3.93 & 0.46 \\
\hline 13. & Rietvlei Dam & $22 / 03 / 05$ & ND & 3.77 & 5.29 & 1.33 \\
\hline 14. & Rietvlei Dam & $26 / 05 / 05$ & ND & 3.78 & 3.99 & 0.58 \\
\hline 15. & Rietvlei Dam & $28 / 07 / 05$ & $\mathrm{ND}$ & 3.27 & 4.78 & 0.37 \\
\hline 16. & Rietvlei Dam $^{1}$ & - & ND & 3.4 & 4.4 & 0.43 \\
\hline 17. & Nzhelele River & $09 / 08 / 08$ & ND & 3.17 & 3.99 & 1.04 \\
\hline 18. & \begin{tabular}{|l|} 
Nzhelele River \\
\end{tabular} & - & ND & 3.27 & 3.83 & 1.3 \\
\hline 19. & Nzhelele River & $27 / 08 / 05$ & $\mathrm{ND}$ & 3.28 & 4.41 & 1.47 \\
\hline 20. & Nzhelele River & $23 / 09 / 05$ & $\mathrm{ND}$ & 3.36 & 3.08 & 1.39 \\
\hline 21. & Mutshindudi River & $09 / 08 / 05$ & $\mathrm{ND}$ & 3.40 & 6.27 & 1.12 \\
\hline 22. & Mutshindudi River $^{1}$ & - & ND & 3.53 & 5.99 & 0.96 \\
\hline 23. & Mutshindudi River & $23 / 09 / 05$ & $\mathrm{ND}$ & 3.28 & 6.80 & 0.72 \\
\hline 24. & Mutshundudi River & $27 / 09 / 05$ & ND & 3.86 & 8.28 & 1.08 \\
\hline 25. & Dzwerani River & $09 / 04 / 05$ & $\mathrm{ND}$ & 3.24 & 5.15 & 0.43 \\
\hline 26. & Lotanyanda River $^{1}$ & $09 / 04 / 05$ & ND & 3.56 & 6.04 & 1.89 \\
\hline 27. & Xikundu River $^{1}$ & $09 / 04 / 05$ & ND & 0.16 & 7.07 & 0.33 \\
\hline 28. & Mutale River $^{1}$ & $27 / 08 / 05$ & ND & 3.31 & 10.17 & 2.18 \\
\hline 29. & Luvuvhu River $^{1}$ & $24 / 09 / 05$ & ND & 3.33 & 3.42 & 0.69 \\
\hline 30. & Dzindi River $^{1}$ & $24 / 09 / 05$ & ND & 3.19 & 5.44 & 0.84 \\
\hline
\end{tabular}

$1.12 \mathrm{mg} / \mathrm{kg}$ in Mutshindudi River sediment. Generally, the levels of phthalates in sediments are consistently higher than those in water samples. This is expected because of possible accumulation of phthalates in sediments as they could act as a 'sink' for phthalates.

The ubiquity of phthalate esters has been widely reported in various environmental samples in developed and developing countries. Their occurrence has been reported in the Greater Manchester River (Fatoki and Vernon, 1990), in Philadelphia drinking water (Suffet et al., 1980) and in tap water from the Municipal Institute of Environmental Sciences, Shinike, Japan (Shinohara, et al., 1981). They were found in the water, fish, and other aquatic organisms of the Gulf of Mexico (Giam et al., 1975) and in sediments and bivalves from the Crouch River estuary (Waldock et al., 1983). Freshwater studies have also revealed detectable concentrations in river water samples in Nigeria (Fatoki and Ogunfowokan, 1993a) and the Eastern Cape Province of South Africa (Fatoki and Noma, 2002).

The levels of phthalate esters reported in this study for the water in rivers and dams are higher than the US Environmental Protection Agency (USEPA) criterion of $3 \mu \mathrm{g} / \ell$ for the protection of fish and aquatic life in rivers (USEPA, 1980). Canada has interim standing water quality guidelines limiting these
Table 5

Variation of phthalate esters $(\mathrm{mg} / \mathrm{kg})$ in sediment

\begin{tabular}{|c|c|c|c|c|c|c|}
\hline $\begin{array}{l}\text { Sample } \\
\text { no }\end{array}$ & Sampling point & Date & DMP & DEP & DBP & DEHP \\
\hline 1 & Marais Dam & $14 / 9 / 04$ & ND & 0.17 & 0.72 & 0.20 \\
\hline 2. & Marais Dam & $23 / 11 / 04$ & ND & 0.16 & 0.23 & 0.03 \\
\hline 3. & Marais Dam & $17 / 1 / 05$ & ND & 0.18 & 0.26 & 0.05 \\
\hline 4. & Marais Dam & $22 / 03 / 05$ & ND & 0.18 & 0.30 & 0.60 \\
\hline 5. & Marais Dam & $28 / 07 / 05$ & ND & 0.16 & 0.27 & 0.04 \\
\hline 6. & Channel & $15 / 9 / 04$ & ND & 0.17 & 0.40 & 0.06 \\
\hline 7 & Channel & 23/11/04 & ND & 0.16 & 0.26 & 0.03 \\
\hline 8. & Channel & $17 / 1 / 05$ & ND & 0.32 & 6.50 & 0.61 \\
\hline 9. & Channel & $22 / 03 / 05$ & 0.16 & 0.17 & 0.40 & 0.04 \\
\hline 10 & Channel & $26 / 05 / 05$ & ND & 0.17 & 0.20 & 0.02 \\
\hline 11. & Channel & $28 / 07 / 05$ & ND & 0.17 & 0.20 & 0.02 \\
\hline 12. & Rietvlei Dam & $15 / 9 / 04$ & ND & 0.17 & 0.40 & 0.02 \\
\hline 13. & Rietvlei Dam & 23/11/04 & ND & 0.16 & 0.23 & 0.02 \\
\hline 14. & Rietvlei Dam & $26 / 05 / 05$ & ND & 0.20 & 0.26 & 0.02 \\
\hline 15. & Vley Dam & $15 / 09 / 04$ & ND & 0.17 & 0.64 & 0.09 \\
\hline 16. & Vley Dam & $23 / 11 / 04$ & ND & 0.16 & 0.21 & 0.02 \\
\hline 17. & Vley Dam & $17 / 01 / 05$ & ND & 0.27 & 0.34 & 0.16 \\
\hline 18. & Vley Dam & $22 / 03 / 05$ & ND & 0.16 & 0.71 & 0.02 \\
\hline 19 & Vley Dam & $26 / 07 / 05$ & ND & 0.16 & 0.28 & 0.02 \\
\hline 20. & Vley Dam & $28 / 07 / 05$ & ND & 0.16 & 0.29 & 0.09 \\
\hline 21. & Nzhelele River & $09 / 08 / 08$ & ND & 0.16 & 0.19 & 0.05 \\
\hline 22. & Nzhelele River & $27 / 08 / 05$ & ND & 0.16 & 0.33 & 0.03 \\
\hline 23. & Nzhelele River & $23 / 09 / 05$ & ND & 0.16 & 0.53 & 0.03 \\
\hline 24. & Mutshindudi River & $09 / 08 / 05$ & ND & 0.17 & 0.89 & 1.12 \\
\hline 25. & Mutshindudi River & $23 / 09 / 05$ & ND & 0.32 & 0.29 & 0.03 \\
\hline 26. & Mutshundudi River & $27 / 09 / 05$ & ND & 0.17 & 0.75 & 0.07 \\
\hline 27. & Dzwerani River & $09 / 04 / 05$ & ND & 0.16 & 0.22 & 0.04 \\
\hline 28. & Lotanyanda River & $09 / 04 / 05$ & ND & 0.12 & 0.32 & 0.02 \\
\hline 29. & Xikundu River & $09 / 04 / 05$ & ND & 0.17 & 0.31 & 0.02 \\
\hline 30. & Mutale River & $27 / 08 / 05$ & ND & 0.16 & 0.29 & 0.06 \\
\hline 31. & Luvuvhu River & $24 / 09 / 05$ & ND & 0.22 & 0.20 & 0.02 \\
\hline 32. & Dzindi River & $24 / 09 / 05$ & ND & 0.16 & 0.36 & 0.02 \\
\hline
\end{tabular}

compounds to such levels as $1.0 \mu \mathrm{g} / \ell$ for DEHP and $19 \mu \mathrm{g} / \ell$ for DBP, for the protection of freshwater aquatic life. California EPA's office of Environmental Health Hazard Assessment has set a public health goal for drinking water of $12 \mu \mathrm{g} / \ell$ for DEHP (Krantz et al., 2000). Although South Africa does not have any regulatory standard for phthalates in its water systems, the Great Lakes Water Agreement lists phthalates among priority pollutants and calls for water standards of: $6 \mu \mathrm{g} / \ell$ DEHP, 4.0 $\mu \mathrm{g} / \ell$ for DBP and $0.2 \mu \mathrm{g} / \ell$ for other phthalates for the protection of aquatic life in the Great Lakes basin ecosystem (Krantz et al., 2000).

Our results for the freshwaters in this study are higher than those reported elsewhere, even for rivers polluted with industrial chemicals. For example, in the Delaware River, USA, 0.3 to 50 $\mu \mathrm{g} / \ell$ for DBP and DEHP was recorded (Sheldon and Hites,. 1979) and in the rivers Irwell and Etherow in the Manchester area, UK, 0.2 to $33.5 \mu \mathrm{g} / \ell$ (Fatoki and Vernon, 1990) was recorded for the phthalates detected in the rivers. The results reported in our study are also higher than those reported for the Ronnebyan River ( 0.32 to $3.10 \mu \mathrm{g} / \ell$ ) and Svartan River ( 0.30 to $1.98 \mu \mathrm{g} / \ell)$, Sweden, (Thuren, 1986). They are, however, comparable to the values recorded for phthalate esters in the rivers of south-western Nigeria (Fatoki and Ogunfowokan, 1993a) but lower than the levels reported for rivers in the Eastern Cape Province of South Africa (Fatoki and Noma, 2002). 


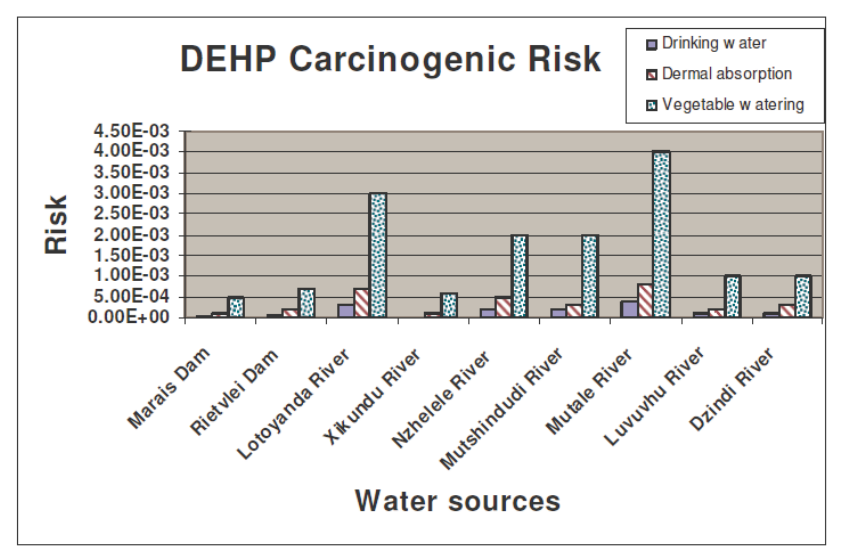

Figure 2

DEHP cancer risk per water use at various water sources

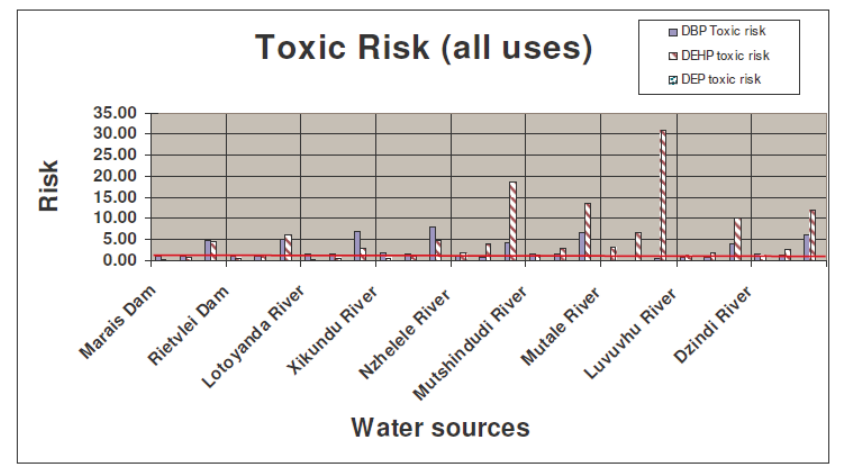

Figure 3

Summary of toxic risks for all exposure routes from all nine water sources

DEHP has generally been recognised as the most commonly used phthalate plasticizer for PVC, at least until recently (Allisorpp et al., 2000). On the contrary, the general pattern emerging from this study was that DBP, used primarily as a plasticizer but which also has a wide variety of non-plasticizer use, such as ingredients in paints, inks, glue, nail polish, hairspray and insect repellents, was found to be the most predominant phthalate ester in the water systems. According to Allisorpp et al. (2000), results like this are an indication of a market shift away from DEHP towards the use of other phthalates, e.g., the much more poorly characterised isomeric phthalates. He further indicated that this shift may be a consequence of serious concerns relating to the suspected health effects of DEHP. Moreover, it is not surprising that DBP was found to be much higher than DEHP in this study because similar work done in the US by Blount et al. (2000) concluded that phthalate exposure is both higher and more common than previously expected, especially for DEHP and DBP as well as other phthalates.

The state of the South African environment regarding phthalate ester plasticizer pollution is currently generating interest. The South African Water Research Commission (WRC), in cooperation with the national Department of Water Affairs and Forestry, launched the endocrine disrupting chemicals(EDCs) monitoring programme of which phthalate esters are an EDC subgroup; these have been monitored in water resources countrywide (Burger et al., 2003). This step highlights the level of concern these chemicals are generating in the South African environment.

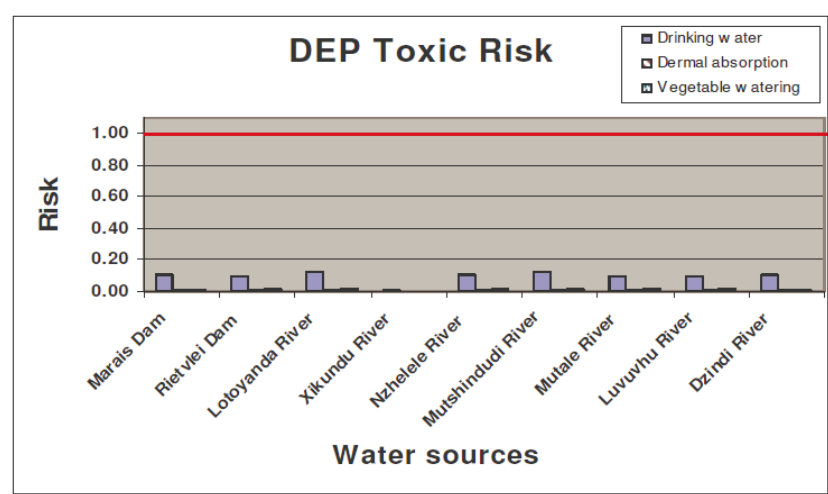

Figure 4

$D E P$ toxic risk via all water uses at nine water sources

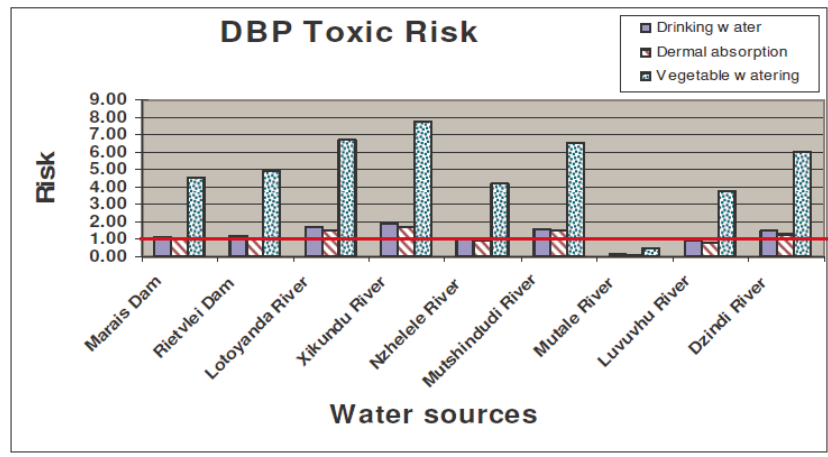

Figure 5

$D B P$ toxic risk via all water uses at nine water sources

Globally there is significant concern for the ubiquitous presence of phthalates in the environment, and scientists, clinicians and regulatory agencies currently debate their potential for causing adverse health effects in humans (NRC, 1983; Kavlock et al., 1996; Hileman, 1996; Patlak, 1996; ATSDR, 2006). Several agencies, including the USEPA, have labelled some phthalates esters, such as DEHP, a probable human carcinogen. One recent study found a strong correlation between testicular cancer and exposure to PVC in workers who make PVC products (US EPA, 1987; WHO, 2003). It was suspected that PVC may have played a significant role in their findings (Cray, 1998). Presently in South Africa, there is a paucity of data on the occurrence and fate of phthalate esters in the aquatic environment and on their possible health effects; hence this study in about the most rural part of South Africa.

Table 6 gives a summary of the carcinogenic as well as toxic risks posed by the various phthalates via different exposure routes for the 9 sampling sites used for the risk assessment study.

DEHP was the only chemical classified as a carcinogen present in the water sources investigated (WHO, 2003). Figure 2 clearly shows that people, who are using untreated water from any of these sources, are exposed to an unacceptable risk of developing cancer $\left(4 \times 10^{-3}\right)$ when, compared to an acceptable cancer risk level of $1 \times 10^{-5}$ as declared by the WHO (2003). DEHP in water poses a serious risk of cancer in humans, especially when using the water for the irrigation of home-grown vegetables, followed by dermal absorption and drinking purposes (Fig. 5).

Based on the concentration of the hazardous chemicals found in the water sources, water from Mutale River posed the 


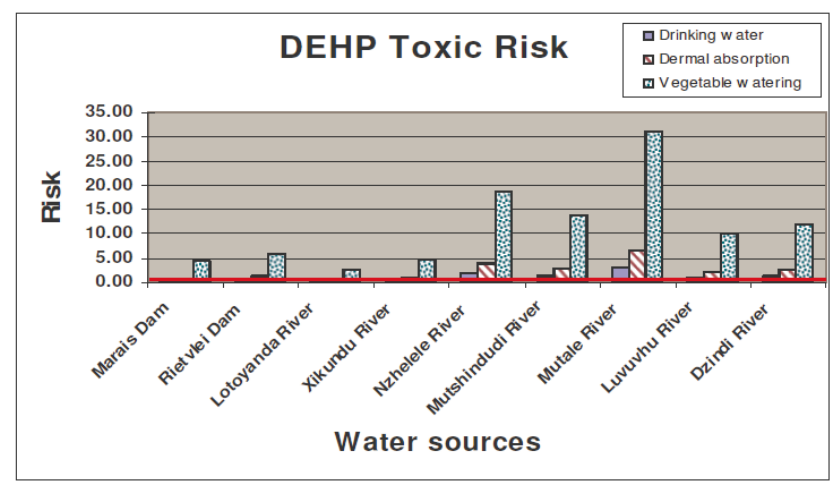

Figure 6

DEHP toxic risk via all water uses at nine water sources

highest human cancer risk for all exposure routes followed by Lotoyanda River.

Figure 3 summarises the toxic health risks posed to human health via all exposure routes when using water polluted with DEP, DBP and DEHP from all 9 water sources. From the figure, it is clear that DEHP posed the highest risk of all the chemicals. Figures 4 to 6 separate the toxicity posed by each chemical. The acceptable risk level or exposure threshold below which no adverse health effects are expected, is indicated with a solid line $(\mathrm{HQ}=1)$. From Fig. 4, it is clear that DEP concentrations found in any of the 9 water sources did not pose a risk of toxic effects to humans $(\mathrm{HQ}=<1)$.
Figures 5 and 6 showed that vegetable watering is the water use (exposure route) that exposes people to the highest risk (also see carcinogenic health risk of DEHP (Fig. 2)). DEHP and DBP posed a probable risk of toxic health effects at all the water sources when used for vegetable watering. The only exception to this was DBP in the Mutale River. DBP did not pose a toxic risk for any water use from the Mutale River. DBP, however, posed a probable toxic risk when consuming untreated water from any of the other 8 sources. Dermal absorption of DBP posed a potential toxic risk at all sources except for the Mutale and Levuvhu Rivers.

Interestingly, the opposite was seen for the concentrations of DEHP found in the Mutale River. DEHP concentrations from the river posed the probable highest toxic risk for all the water uses with vegetable watering having a hazard quotient of 31 times higher than the acceptable risk limit $(\mathrm{HQ}=31)$ (Fig. 6). DEHP concentrations at all 9 water sources posed potential toxic effects when irrigating home-grown vegetables with untreated water. Except for the Mutale River, DEHP constituted a potential toxic risk based on dermal absorption at 4 other sources. These include the Nzhele, Mutshindudi, Levuvhu and Dzindi Rivers.

Although endocrine disruption effects are of serious concern, the data necessary to apply a quantitative risk assessment are unavailable at this stage. One can, however, assume that at the levels detected, some endocrine disruption would occur as toxic and carcinogenic effects are observed at levels higher than endocrine disruption.

\begin{tabular}{|c|c|c|c|c|c|}
\hline \multicolumn{6}{|c|}{$\begin{array}{c}\text { Table } 6 \\
\begin{array}{c}\text { Carcinogenic and toxic risks as a result of exposure to phthalates via } \\
\text { different routes of exposure }\end{array}\end{array}$} \\
\hline Water source & \begin{tabular}{|l|}
$\begin{array}{l}\text { Water use/exposure } \\
\text { route }\end{array}$ \\
\end{tabular} & $\begin{array}{c}\text { Cancer } \\
\text { risk } \\
\text { DEHP }\end{array}$ & $\begin{array}{l}\text { Toxic } \\
\text { Risk } \\
\text { DBP }\end{array}$ & $\begin{array}{c}\text { Toxic } \\
\text { Risk } \\
\text { DEHP }\end{array}$ & $\begin{array}{l}\text { Toxic } \\
\text { Risk } \\
\text { DEP }\end{array}$ \\
\hline Marais Dam & $\begin{array}{l}\text { Drinking } \\
\text { Dermal absorption } \\
\text { Vegetable watering }\end{array}$ & $\begin{array}{l}5.00 \mathrm{E}-05 \\
1.00 \mathrm{E}-04 \\
5.00 \mathrm{E}-04\end{array}$ & $\begin{array}{l}1.14 \\
1.00 \\
4.60\end{array}$ & $\begin{array}{l}0.40 \\
0.90 \\
4.30\end{array}$ & $\begin{array}{l}0.11 \\
0.01 \\
0.01\end{array}$ \\
\hline Rietveli Dam & $\begin{array}{l}\text { Drinking } \\
\text { Dermal absorption } \\
\text { Vegetable watering }\end{array}$ & $\begin{array}{l}7.00 \mathrm{E}-05 \\
2.00 \mathrm{E}-04 \\
7.00 \mathrm{E}-04\end{array}$ & $\begin{array}{l}1.20 \\
1.10 \\
4.90\end{array}$ & $\begin{array}{l}0.60 \\
1.30 \\
6.00\end{array}$ & $\begin{array}{l}0.10 \\
0.01 \\
0.02\end{array}$ \\
\hline Lotoyanda River & $\begin{array}{l}\text { Drinking } \\
\text { Dermal absorption } \\
\text { Vegetable watering }\end{array}$ & $\begin{array}{l}3.00 \mathrm{E}-04 \\
7.00 \mathrm{E}-04 \\
3.00 \mathrm{E}-03\end{array}$ & $\begin{array}{l}1.70 \\
1.50 \\
6.70\end{array}$ & $\begin{array}{l}0.30 \\
0.60 \\
2.70\end{array}$ & $\begin{array}{l}0.12 \\
0.01 \\
0.02\end{array}$ \\
\hline Xikundu River & $\begin{array}{l}\text { Drinking } \\
\text { Dermal absorption } \\
\text { Vegetable watering }\end{array}$ & $\begin{array}{l}5.00 \mathrm{E}-06 \\
1.00 \mathrm{E}-04 \\
6.00 \mathrm{E}-04\end{array}$ & $\begin{array}{l}1.90 \\
1.70 \\
7.80 \\
\end{array}$ & $\begin{array}{l}0.50 \\
1.00 \\
4.70 \\
\end{array}$ & $\begin{array}{l}0.01 \\
0.00 \\
0.00 \\
\end{array}$ \\
\hline Nzhelele River & $\begin{array}{l}\text { Drinking } \\
\text { Dermal absorption } \\
\text { Vegetable watering }\end{array}$ & $\begin{array}{l}2.00 \mathrm{E}-04 \\
5.00 \mathrm{E}-04 \\
2.00 \mathrm{E}-03\end{array}$ & $\begin{array}{l}1.00 \\
0.90 \\
4.20\end{array}$ & $\begin{array}{c}1.80 \\
3.80 \\
18.60\end{array}$ & $\begin{array}{l}0.11 \\
0.01 \\
0.02\end{array}$ \\
\hline Mutshindudi River & $\begin{array}{l}\text { Drinking } \\
\text { Dermal absorption } \\
\text { Vegetable watering }\end{array}$ & $\begin{array}{l}2.00 \mathrm{E}-04 \\
3.00 \mathrm{E}-04 \\
2.00 \mathrm{E}-03\end{array}$ & $\begin{array}{l}1.60 \\
1.50 \\
6.60\end{array}$ & $\begin{array}{c}1.30 \\
2.80 \\
13.70 \\
\end{array}$ & $\begin{array}{l}0.12 \\
0.01 \\
0.02\end{array}$ \\
\hline Mutale River & $\begin{array}{l}\text { Drinking } \\
\text { Dermal absorption } \\
\text { Vegetable watering }\end{array}$ & $\begin{array}{l}4.00 \mathrm{E}-04 \\
8.00 \mathrm{E}-04 \\
4.00 \mathrm{E}-03\end{array}$ & $\begin{array}{l}0.12 \\
0.10 \\
0.50\end{array}$ & $\begin{array}{c}3.0 \\
6.40 \\
31.00\end{array}$ & $\begin{array}{l}0.10 \\
0.01 \\
0.02\end{array}$ \\
\hline Luvuvhu River & $\begin{array}{l}\text { Drinking } \\
\text { Dermal absorption } \\
\text { Vegetable watering }\end{array}$ & $\begin{array}{l}1.00 \mathrm{E}-04 \\
2.00 \mathrm{E}-04 \\
1.00 \mathrm{E}-03\end{array}$ & $\begin{array}{l}0.90 \\
0.80 \\
3.80\end{array}$ & $\begin{array}{c}1.00 \\
2.00 \\
10.00\end{array}$ & $\begin{array}{l}0.10 \\
0.01 \\
0.02\end{array}$ \\
\hline Dzindi River & $\begin{array}{l}\text { Drinking } \\
\text { Dermal absorption } \\
\text { Vegetable watering }\end{array}$ & $\begin{array}{l}1.00 \mathrm{E}-04 \\
3.00 \mathrm{E}-04 \\
1.00 \mathrm{E}-03\end{array}$ & $\begin{array}{c}1.50 \\
1.30 \\
6\end{array}$ & $\begin{array}{c}1.20 \\
2.50 \\
12\end{array}$ & $\begin{array}{l}0.11 \\
0.01 \\
0.01\end{array}$ \\
\hline
\end{tabular}




\section{Uncertainty analysis}

All risk estimates involve some degree of uncertainty and uncertainty exists at numerous levels. Uncertainty regarding exposure has 2 primary sources: uncertainty about contamination including concentrations of chemicals to which the potential population may be exposed over the duration of the exposed period, and uncertainty about exposed population. In this study both of these were significant. The exposed population could not be studied and the health risk is based solely on hypothetical exposure scenarios. Therefore, uncertainty in the results may be substantial (Risk Assistant ${ }^{\mathrm{TM}}$, 1995).

Uncertainty in dose-response (carcinogenic and toxicological) data also exists. The reference doses used have uncertainty factors of 1 or 2 orders of magnitude. The various assumptions used (e.g., lifetime of $70 \mathrm{yr}$, body weight of $70 \mathrm{~kg}$, etc) increases the uncertainties involved in the assessment process (Risk Assistant $^{\mathrm{TM}}$, 1995).

Thus the results provided in this study are merely an indication of the potential health risk associated with potential exposure to river waters if used for domestic and other purposes. It is possible that these risks predicted may be an underrepresentation of health risks as they only portray the risks if a population is exposed to these particular phthalates. No other chemicals were included in the study, but the likelihood of other chemicals being present in the river waters is high. Therefore health risk may in fact be greater than what is represented in this paper (Risk Assistant ${ }^{\mathrm{TM}}, 1995$ ).

\section{Conclusion}

Phthalate ester plasticizers determined in the freshwater samples were found at elevated levels which give cause for concern Based on the concentrations found in the rivers at the 9 water sources and the assumptions used, DEHP posed the highest potential risk potential of all phthalates (both toxic and carcinogenic). The water use or exposure pathway that posed the highest potential health risk for carcinogenic as well as toxic effects was vegetable watering. This further emphasises the need for proper monitoring of the levels of these chemicals in the South African water systems in order to promote human health and the 'health' of the ecosystem, if this does not presently exist.

\section{Acknowledgement}

The authors would like to thank Water Research Commission, South Africa for funding the research.

\section{References}

ALASTRISTE-MONDRAGON F, IRANPURB R and AHRINGA BK (2003) Toxicity of di-(2-ethylhexyl) phthalate on the anaerobic digestion of wastewater sluge. Water Res. 37 1260-1269.

ALLIZORPP M, SINTILLO D and JOHNSON P (2000) Hazardous chemicals in PVC flooring, Greenpeace Research Laboratory Technical Note: 14/00 http://eugreenpeace.org/downloads/chem/ pvc.

ARCADI R, COSAT C and IMPERATORE C (1998) Oral toxicity of DEHP during pregnancy and sucking in the long-evans rat. Food Chem. Toxicol. 36 963-974.

ATSDR (2006) Agency for Toxic Substances and Disease Registry. US Department of Health and Human Services, Atlanta, Georgia.

BLOUNT BC, SILVA MJ, CAUCILL SP, NEEDHAM LL, PIRKLE JL, SAMPSON EJ, LUCIIER GW, JACKSON RJ and BROCK JW (2000) Environ. Health Perspect. 108 (10) 979-982.
BURGER AEC, BORNMAN MS, DEJAGER CA, VAN WYK JH, VAN ZYL PVC, SLABBERT JL, MEINNARDT HR and FATOKI O (2003) Endocrine Disruptors in Aquatic Systems of South Africa. $1^{\text {st }}$ Draft Report on WRC Project No. K5/1402. Water Research Commission, Pretoria, South Africa.

CATHERINE A, HARRIS J and SUMPTER JP (2001) The endocrine disrupting potential of phthalates. In: Metzler M (ed.) Endocrine Disruptors, Part 1. 169-201.

COLBORN T, VOM SAAL FS and SOTO AM (1993) Development effects of endocrine-disrupting chemicals in wild-life and humans. Environ. Health Perspect. 101 378-384.

COLON I, CARO D, CARLOS J, BOURDONY J and ROSSARIO O (2000) Identification of phthalate esters in the serum of young Puerto Riccan Girls. Environ. Environ. Health Perspect. 108 (9) 895-900.

CRAY C (1998) Experimenting on children. Www.greenleft.au back/1998/327p.25.htm

FATOKI OS and VERNON F (1990) Phthalate esters in the rivers of greater Manchester area, UK. Sci. Total Environ. 95 227-232.

FATOKI OS and OGUNFOWOKAN AO (1993a) Determination of phthalate esters plasticizers in the aquatic environment of South Western Nigeria. Environ. Int. 19 619-623.

FATOKI OS and OGUNFOWOKAN AO (1993b) Procedural clean-up technique for the determination of phthalate esters in an aquatic environment. Int. J. Environ. Stud. 44 237-243.

FATOKI OS and NOMA A (2002) Sold phase extraction method for selective determination of phthalate esters in the aquatic environment. Water Air Soil Pollut. 140 85-98.

FREDRICSSON B, MULLER L, POUSETTE A and WESTERHLM R (1993) Human sperm mobility is affected by plasticizers and diesel particle extracts. Pharmacol. Toxicol. 72 128-133.

GIAM CS, CHAU HS and NEFF GS (1975) Sensitive method for the determination of phthalate ester plasticizers in open ocean biota samples. Anal. Chem. 47 2225-2228.

GIAM CS and WONG WK (1972) Problems of background contamination in the analyses of open ocean biota for chlorinated hydrocarbons. J. Chromatogr. 72 282-292.

GIUST JA, SEIPELT T ANDERSON BK, DEIS DA and HINDERS JD (1990) Determination of Bis (2-ethylhexyl) phthalate in cow's milk and infant formular by high performance liquid chromatography. J. Agric. Food Chem. 38 415-418.

HARRIS CA, HENTU P, PARKER MG and SUMPTER JP (1997) The estrogenic activity of phthalate esters in vitro. Environ. Health Perspect. 105 802-811.

HILEMAN B (1996) Environmental hormone disrupters focus of major research initiatives. Chem. Eng. News 74 28-35.

HITES RA (1973) Analysis of trace organic compounds in New England Rivers. J. Chromatogr. Sci. 11 570-574.

HUANG P-C, TIEN C-J, SUN Y-M, HSIEH C-Y and LEE C-C (2008) Occurrence of phthalates in sediment and biota: Relationship to aquatic factors and the biots-sediment accumulation factor Chemosphere 73 539-544.

HUFF JE and KLUWE WM (1984) Phthalate ester carcinogenicity in F344/N rats and B6C3F mice. Prog. Clin. Biol. Res. 141 137-154.

IMAJIMA T, SHONO T, ZAKARIA O and SUITA S (1993) Prenatal phthalate cause cryptorchidism postnatally by inducing Trans abdominal ascent of the testis in fetal rats. J. Pediatr. Surg. 32 $18-21$.

JENG W (1986) Phthalate ester in marine sediments around Taiwan. Act Oceanogr. Taiwanica 17 61-68.

KAVLOCK RJ, DASTON GP, DELROSA C, FENNER-CRISP P, GRAY LE, KAATTARI S, LUCIER G, LUSTER M, MAC MJ and MACZKA C (1996) Research needs for the risk assessment of health and environmental effects of endocrine disruptors: A report of the USEPA-sponsored workshop. Environ. Health Perspect. 104 (4) 715-740

KRANTZ A, TUPPER R and TICHNER JA (2000) Phthalates. Health Effects Rev. 3 (4) 1-2.

LI X, ZHONG M, XNC S and SUN C (2006) Determination of phthalates in water samples using polyaniline-based solid-phase microextraction coupled with gas chromatography. J. Chromatgr. A 1135 101-108. 
LING W, GUI-BIN C, YA-QI H, BIN YA-WEI W and DA-ZHONG $S$ (2007) Cloud point extraction coupled with HPLC-UV for the determination of phthalate esters in environmental water samples. J. Environ. Sci. 19 874-878.

MARIN ML, LOPEZ J, SANCHEZ A, VILAPLANA J and JIMENEZ A (1998) Analysis of potential toxic phthalate plasticizers used in toy manufacturing. Bull. Environ. Contam. Toxicol. 60 68-73.

MAYER FL (1976) The Dynamics of the Di-2-ethyl phthalates in Fathead Minnows. J. Fish Reserve Board-Canada 33 2610-2613.

MILLER JC and MILLER JN (1984) Statistics for Analytical Chemistry, Ellis Horwood, Chichester, Chichester. 96 pp.

MYLCHREEST E, CATTLEY R and FORSTER P (1998) Male reproductive tract malformations in rats following gestational and lactational exposure to Di (n-butyl) phthalate: An antiandorgenic mechanism? Toxicol. Sci. 4347.

NRC (National Research Council) (1983) Risk Assessment in the Federal Government: Managing the Process. National Academy of Sciences, National Academy Press, Washington, DC.

PATLAK DB (1996) Testing deadline for endocrine disrupters. Environ. Sci. Technol. 30 540A-544A.

PEKALL DB (1975) Phthalate esters: occurrence and biological effects. Residue Rev. 541.

PIERCE RC, MATHUR SF, WILLIAMS DT and BIDDINGTON MJ (1980) Phthalate Esters in the Aquatic Environment. NRCC/CNRC, Ottawa, Ontario, Canada. 108 pp.

POON R, LECAVALIERT P, MUELLER R, VALLI V, PROCTER B and CHU I. (1997) Subchronic oral toxicity of Di-n-octyl phthalate and Di (2-ethylhexyl) phthalate in plastic toys. Chromatographia 47 724-726

RISK *ASSISTANT ${ }^{\mathrm{TM}}$ (1995) Hampshire Research Institute. Thistle Publishers, Alexandria, VA, USA

RISK *ASSISTANT ${ }^{\text {TM }}$ (1996) Hampshire Research Institute. Thistle Publishers, Alexandria, VA, USA.

RITSENA R, COFINO WP, FRINTOP PGM and TH. BRINKMAN UA (1989) Trace-level analysis of phthalate in surface waters and suspended particulate matter by means of capillary gas chromatography with electron capture detection. Chemosphere $\mathbf{1 8}$ 2161-2175.

SHANKER RC, RAMAKRICHMA C and SETH P (1985) Degradation of some phthalic acid esters in soil. Environ. Pollut. 39 1-5.

SHEA PJ, WEBER JB and OVERCASH MR (1982) Uptake and phytotoxicity of Di-n.-butyl phthalate in corn (Zea mays). Bull. Environ. Contam. Toxicol. 29 153-158.

SHELDON SC and HITES RA (1979) Organic compounds in Delaware River. Environ. Sci. Technol. 12 1188-1194.
SHINOHARA R, KIDIO A, ETO S, HORI T, KOGA M and AKIYAMA T (1981) Identification of trace organics in tap water by computerized gas-chromatography-mass spectrometry. Water Res. 15 535-542.

SUFFET TH, BRENNER L and CAIRO P R (1980) Identification of trace organics in Philadelphia drinking waters during a 2-year period. Water Res. 14853.

THUREN A (1986) Determination of phthalates in aquatic environment. Bull. Environ. Contam. Toxicol. 36 33-40.

TANAKA K and TAKESHITA M (1984) Determination of total phthalate esters in waste waters by differential pulse polarography. Anal. Chim. Acta 166 153-161.

TOMITA I, NAKAMURA Y, AOKI N and INNI N (1982) Mutagenic/ Carcinogenic potential of DEHP and MEHP. Environ. Health Perspect. 14 119-125.

US EPA (UNITED STATES ENVIRONMENTAL PROTECTION AGENCY) (1980) Ambient Water Quality Criteria for Phthalate Esters. Office of Water Regulations and Standards, Criteria and Standard Division, US EPA, 1980, 440/5-80-0687. Washington, DC.

US EPA (UNITED STATES ENVIRONMENTAL PROTECTION AGENCY (1987) Risk Assessment Guidelines of 1986. EPA/600/887/045. Office of Health and Environmental Assessment. Washington, DC.

US EPA (UNITED STATES ENVIRONMENTAL PROTECTION AGENCY (1992) Guidelines for Exposure Assessment. EPA/600/Z-92/001. Risk Assessment Forum, US EPA, Washington, DC.

VONIER PM, CRAIN DA, McLACHLAN JA, GUILLETTE L (Jr.) and ARNOLD S F (1996) Interaction of environmental chemicals with estrogen and progesterone receptors from the oviduct of the American alligator. Environ. Health Perspect. 104 1318-1322.

WALDOCK JM (1983) Determination of phthalate esters in samples from the marine environment using gas chromatography-mass spectrometry. Chem. Ecol. 1 61-277.

WHO (World Health Organization) (1996) Guidelines for Drinking Water Quality. Volume 12. Recommendations. WHO, Geneva. WHO (World Health Organization) (2003) State of the Art Report. Health Risks in Aquifer Recharged Using Reclaimed Water. Water, Sanitation and Health. Protection and Human Environment. SDE/ WSH/03.08. WHO, Geneva.

YUAN SY, LIU C, LIAO CS and CHANG BV (2002) Occurrence and microbial degradation of phthalate esters in Taiwan river sediments. Chemosphere 49 1295-1299.

YUAN B, LI Z and GRAHAM N (2008) Aqueous oxidation of dimethyl phthalate in a $\mathrm{Fe}(\mathrm{VI})-\mathrm{TiO}_{2}-\mathrm{UV}$ reaction system. Water Res. 42 $1413-1420$. 
